\title{
A Case of Dental Prosthesis Aspiration in a Patient with Tracheostomy
}

\author{
Trakeostomili Bir Hastada Dental Protez Aspirasyonu
}

Nurhan Atilla', Hüseyin Arpağ' ${ }^{1}$ Şemi Atilla², ilim Irmak ${ }^{3}$, Ahmet Beyaz'

\section{Abstract}

A 49-year-old male patient was hospitalized to our chest intensive care unit with the diagnosis of recurrent pneumonia. Following a traffic accident five years previously the patient was quadriplegic and had a tracheostomy tube. His physical examination revealed widespread expiratory rhonchi and intercostal retractions. Right lower lobe atelectasis, and also a foreign body at the entrance of the right lower lobe, was seen with a posteroanterior chest $x$-ray and thoracic computed tomography. We saw that the foreign body was present at the chest x-ray performed immediately after the accident. It is probable that dental trauma occurred during intubation. In a fiberoptic bronchoscopy, a foreign body was identified in the proximal part of the right lower bronchus; a second foreign body was seen at the segment level. The foreign bodies were removed using an alligator biopsy forceps without damaging the surrounding tissue; there were no complications. The foreign bodies were teeth and a dental prosthesis. In conclusion, in patients who have sustained facial or dental trauma, including traumatic intubations, and who have a missing tooth, it must be presumed that the tooth has been aspirated, and radiographic evaluation is needed.

Key words: Aspiration, dental prothesis, fiberoptic bronchoscopy.

\section{Özet}

Kırk dokuz yaşında erkek hasta tekrarlayan pnömoni nedeniyle göğüs hastalıkları yoğun bakım ünitesine yatırıldı. Hasta beş yıl önce bir trafik kazası geçirmişti. Bu nedenle kuadriplejikti ve trakeostomi tüpü vardı. Fizik muayenede yaygın ekspiratuvar ronküsler ve interkostal çekilmeleri mevcuttu. Posteroanterior akciğer grafisinde ve toraks bilgisayarlı tomografisinde sağ alt lob atelektazisi ve aynı zamanda sağ alt lob girişinde yabancı cisim saptandı. Yabancı cismin kazadan hemen sonra çekilen akciğer grafisinde de mevcuttu. Dental travma muhtemelen entübasyon sırasında oluşmuştu. Fiberoptik bronkoskopi ile bakıldığında sağ alt lob girişinde yabancı cisim olduğu görüldü. Segment düzeylere bakıldığında ikinci bir yabancı cisim fark edildi. Yabancı cisimler çevre dokulara zarar vermeden timsah biyopsi forsepsi ile çıkarıldı. Herhangi bir komplikasyon olmadı. Yabancı cisimlerin diş ve protez olduğu görüldü. Sonuç olarak, travmatik entübasyon dâhil olmak üzere, yüz ya da diş travması geçiren hastalarda ağız içi gözden geçirilmeli, özellikle eksik diş varlığında aspirasyon ihtimali gözönünde bulundurulmalı ve radyolojik değerlendirme yapılmalıdır.

Anahtar Sözcükler: Aspirasyon, diş protezi, fiberoptik bronkoskopi.

\footnotetext{
'Department of Chest Diseases, Kahramanmaraş Sütçü İmam University, Kahramanmaraş, Turkey

${ }^{2}$ Clinic of Chest Diseases, Kahramanmaraş Necip Fazıl State Hospital, Kahramanmaraş, Turkey

${ }^{3}$ Clinic of Chest Diseases, Süreyya Adanalı State Hospital, Kahramanmaraş, Turkey

\author{
'Kahramanmaraş Süłçü İmam Üniversitesi, Göğüs Hastalıkları \\ Anabilim Dalı, Kahramanmaraş \\ ${ }^{2}$ Kahramanmaraş Necip Fazıl Şehir Hastanesi, Göğüs Hasta- \\ lıkları Kliniği, Kahramanmaraş \\ ${ }^{3}$ Süreyya Adanalı Devlet Hastanesi, Göğüs Hastalıkları Kliniği, \\ Kahramanmaraş
}

Submitted (Başvuru tarihi): 15.06.2015 Accepted (Kabul tarihi): 31.07.2015

Correspondence (iletişim): Nurhan Atilla, Department of Chest Diseases, Kahramanmaraş Sütçü İmam University, Kahramanmaraş, Turkey e-mail: nurhanatillag@hotmail.com 
Elderly patients, particularly those with primary neurologic disorders and decreased gag reflexes due to alcohol, seizures, strokes, Parkinsonism, trauma, and senile dementia, are also at risk of aspiration; any number of objects, food, and stomach contents can be aspirated. Initially, the diagnosis is often missed, particularly in patients where the history may be vague and the patient cannot verbalize events.

It is important to remove the foreign body quickly and safely, and to relieve the clinical symptoms of the patient, in order to prevent the possibility of serious complications. While mostly rigid bronchoscopy is used to remove foreign bodies from the tracheobronchial system in children, both rigid and fiberoptic bronchoscopy (FOB) may be used in adults, particularly those with tracheostomy.

\section{CASE}

A 49-year-old male patient was hospitalized in our chest intensive care unit with a diagnosis of recurrent pneumonia. The patient had been in a traffic accident five years before and as a result was quadriplegic and had tracheostomy tube. His physical examination revealed widespread expiratory rhonchi and intercostal retractions. Right lower lobe atelectasis and also a foreign body at the entrance of right lower lobe was seen at posteroanterior chest $x$-ray and thoracic computed tomography (Figure 1 and 2). We saw that the foreign body was present at the chest $x$-ray performed after the accident. This was probably due to dental trauma that occurred during intubation. In fiberoptic bronchoscopy, a foreign body was identified in the proximal part of the right lower bronchus (Figure 3). The foreign body was removed using an alligator biopsy forceps without damaging the surrounding tissue; there were no complications or bleeding. A dental prosthesis and a tooth were removed (Figure 4). After the bronchoscopy, dyspnea was resolved and rhonchi detected in his physical examination disappeared. He received empirical nonspecific antibiotic treatment.

\section{DISCUSSION}

Foreign body aspiration can be a life-threatening emergency. An aspirated solid or semisolid object may lodge in the larynx or trachea. If the object is large enough to cause nearly complete obstruction of the airway, asphyxia may cause rapid death. Lesser degrees of obstruction or passage of the obstructive object beyond the carina can result in less severe signs and symptoms. Location of the foreign body in the airway is associated with the anatomical structure of the tracheobronchial tree and the posture of the individual during aspiration (1). Most of the foreign bodies lodge in the right main stem bronchi and distal bronchi, as the right main bronchus is more vertically aligned and its diameter is wider compared with the left main bronchus $(2,3)$. In the case presented here, the foreign body was detected in the distal part of the right intermediate bronchus.

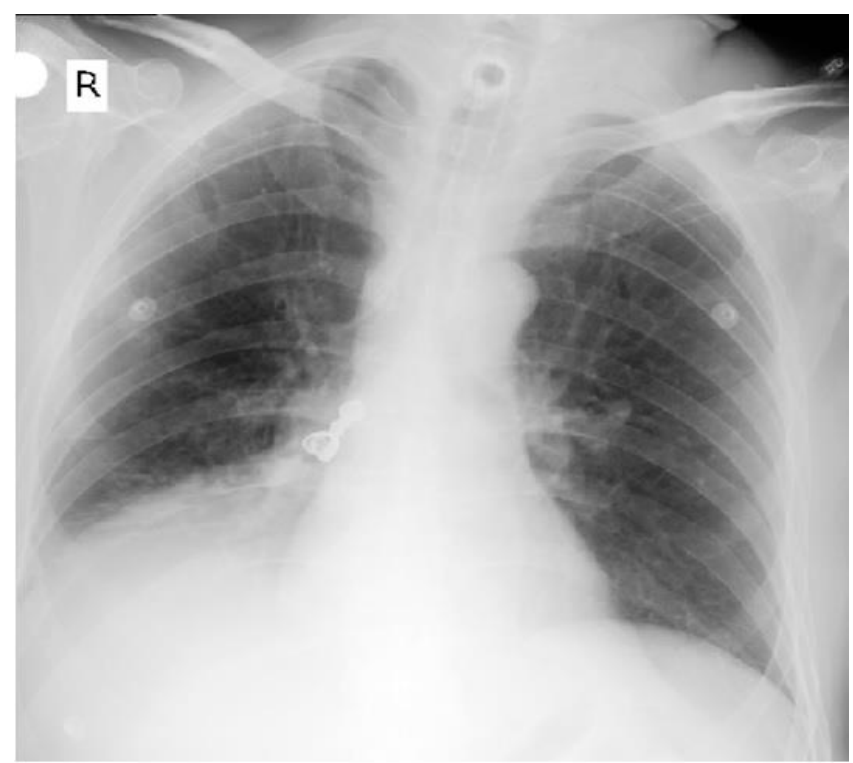

Figure 1: Right lower lobe atelectasis and also a foreign body at the entrance of right lower lobe was seen at posteroanterior chest $x$-ray

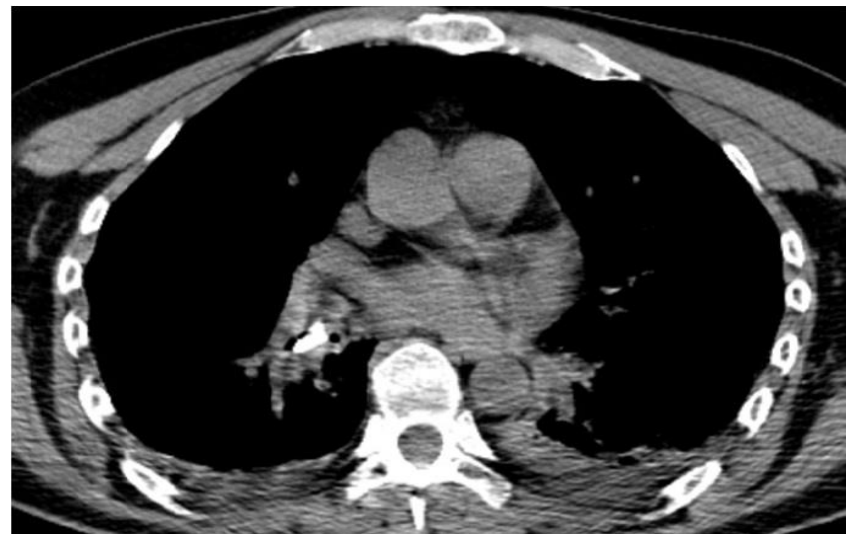

Figure 2: Right lower lobe atelectasis and also a foreign body at the entrance of right lower lobe was seen at posteroanterior thoracic computed tomography

Chronic debilitating symptoms with recurrent infections might occur with delayed extraction, or the patient may remain asymptomatic. The actual aspiration event can usually be identified, although often it is not immediately recognized. The aspirated object might even escape detection. Most frequently, the aspirated object is food, but a broad spectrum of aspirated items has been documented over the years. Commonly retrieved objects include seeds, nuts, bone fragments, nails, small toys, coins, pins, 
medical instrument fragments, and dental appliances. In our case, the aspirated foreign body was dental prosthesis and a tooth.

The most important factors in diagnosis are a detailed anamnesis, respiratory system examination, and the accurate localization of the foreign body with the help of radiological methods. Chest $x$-rays taken from two positions prior to bronchoscopy generally show the accurate localization of the foreign body (4). When TFBA (Traumatic Foreign Body Aspiration) is suspected, radiological imaging techniques should be used. If the foreign body is radiopaque, it can easily be detected by posteroanterior chest $\mathrm{x}$-rays. However, in order to correctly locate and determine the size of the foreign body, lateral and oblique chest x-rays should also be taken, and if required, thoracic computed tomography should also be obtained (5). Although a normal chest $x$-ray does not rule out foreign bodies, if the clinical suspicion remains, a bronchoscopic examination is inevitable. In our case, the diagnosis was made with chest $x$-ray and thoracic computed tomography.

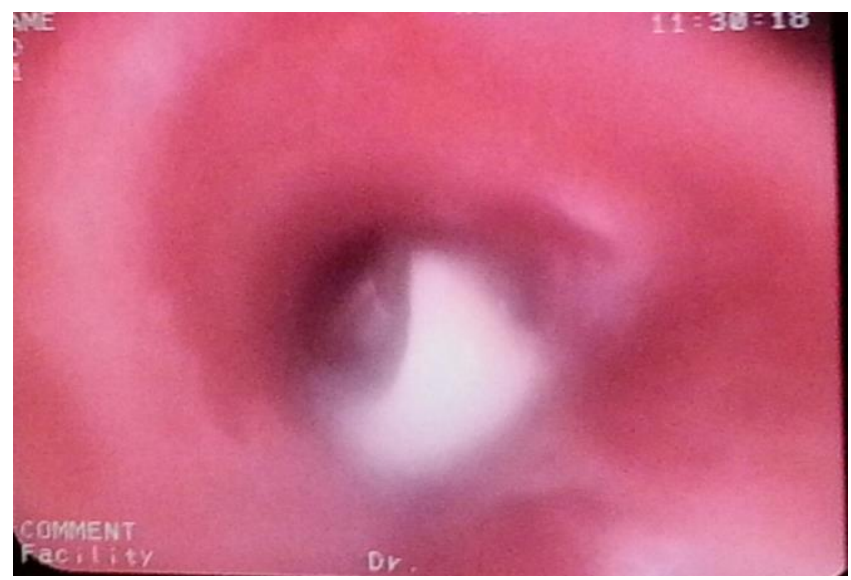

Figure 3: In fiberoptic bronchoscopy, a foreign body was identified in the proximal part of the right lower bronchus

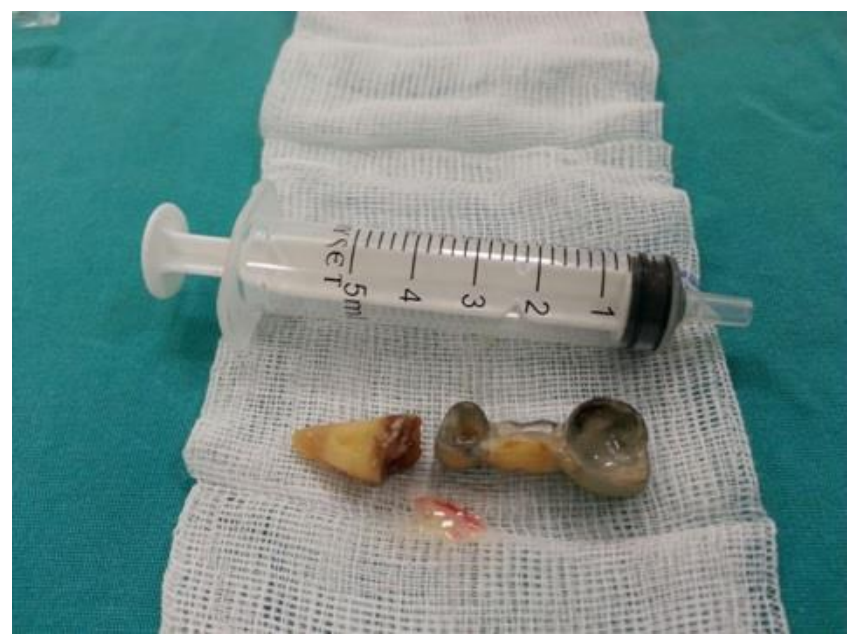

Figure 4: The dental prosthesis and its tooth removed
The most contemporary treatment method for tracheobronchial foreign body aspirations is the removal of the foreign body by rigid bronchoscopy under general anesthesia. It is emphasized that all cases with a history of TFBA should undergo bronchoscopy; however, in order to prevent morbidity from foreign body aspirations that may be overlooked, some negative consequences are inevitable, but with sufficient experience and suitable patient selection, the success rate of FOB in TFBA is high $(6,7)$. As the patient had a tracheostomy, the foreign body was removed successfully by fiberoptic bronchoscopy.

In adults, the factors that increase risk are underlying primary neurologic disorders, such as senile dementia, mental retardation, seizures, strokes, and Parkinsonism. Conditions that depress the central nervous system, cause coma, or depress the gag reflex, such as alcohol, narcotics, barbiturates, or benzodiazepines, can increase the likelihood of aspiration. Meat, bones, and medical and dental appliances are the most commonly aspirated objects in adults. Local inflammation, edema, cellular infiltration, ulceration, and granulation tissue formation, may contribute to airway obstruction while making bronchoscopic identification and removal of the object more difficult. The airway becomes more likely to bleed with manipulation; the object is more likely to be obscured and becomes more difficult to dislodge. Mediastinitis or tracheoesophageal fistulas may result. Distal to the obstruction, air trapping may occur, leading to local emphysema, atelectasis, hypoxic vasoconstriction, postobstructive pneumonia, and the possibility of volume loss, necrotizing pneumonia or abscess, suppurative pneumonia, or bronchiectasis.

In conclusion, in patients who have sustained facial or dental trauma, including traumatic intubations and who have a missing tooth, it must be presumed that the tooth has been aspirated, and radiographic evaluation is needed.

\section{CONFLICTS OF INTEREST}

None declared.

\section{AUTHOR CONTRIBUTIONS}

Concept - N.A., H.A., S..A., I.I., A.B.; Planning and Design - N.A., H.A., S..A., I.I., A.B.; Supervision - N.A., H.A., S.A., I..l., A.B.; Funding -; Materials -; Data Collection and/or Processing -; Analysis and/or Interpretation -; Literature Review - N.A., H.A., S..A., I.I., A.B.; Writing N.A.; Critical Review - H.A., N.A., Ş.A., i..., A.B. 


\section{YAZAR KATKILARI}

Fikir - N.A., H.A., S..A., i.ı., A.B.; Tasarım ve Dizayn N.A., H.A., S.A., I.I., A.B.; Denetleme - N.A., H.A., S..A., i.I., A.B.; Kaynaklar -; Malzemeler -; Veri Toplama ve/veya İsleme -; Analiz ve/veya Yorum -; Literatür Taraması - N.A., H.A., S..A., İ.ı., A.B.; Yazıyı Yazan - N.A.; Eleştirel İnceleme - H.A., N.A., Ş.A., I.I., A.B.

\section{REFERENCES}

1. Rafanan AL, Mehta AC. Adult airway foreign body removal. What's new? Clin Chest Med 2001; 22:319-30.

2. Dikensoy $O$, Usalan C, Filiz A. Foreign body aspiration: clinical utility of flexible bronchoscopy. Postgrad Med J 2002; 78:399-403. [CrossRef]
3. Çelik P, Yorgancıoğlu A, Çelik O. Laringotracheobronchial foreign body aspiration. KBB Klinikleri 2000; 2:50-6.

4. Sefa N, Ünsal Ş, Çağırıcı U, Çakan A, Buduneli T. Tracheobronchial foreign bodies. İzmir Göğüs Hastanesi Dergisi 1996; 2:26-31.

5. Beşirli K, Demirkaya A. Tracheobronchial foreign body aspiration. Solunum 2003; 5:316-9.

6. Mantor PC, Tuggle DW, Tunell WP. An appropriate negative broncoscopy rate in suspected foreign body aspiration. Am J Surg 1989; 11:837-41.

7. Marquette $\mathrm{CH}$, Martinot $\mathrm{A}$. Foreign body removal in adults and children. In: Bollinger CT, ed. Interventional Bronchoscopy. Basel: S Karger AG; 2000:96-107. [CrossRef] 